\title{
Mammalian Stem Cells
}

\author{
ALEXEY V. TERSKIKH, PETER J. BRYANT, AND PHILIP H. SCHWARTZ
}

Burnham Institute for Medical Research [A.V.T], La Jolla, CA 92037; Children's Hospital of Orange County [P.J.B.], Orange, CA 92868; Developmental Biology Center [P.H.S.], University of California, Irvine, CA 92717

\begin{abstract}
Stem cells are quickly coming into focus of much biomedical research eventually aiming at the therapeutic applications for various disorders and trauma. It is important, however, to keep in mind the difference between the embryonic stem cells, somatic stem cells and somatic precursor cells when considering potential clinical applications. Here we provide the review of the current status of stem cell field and discuss the potential of therapeutic applications for blood and Immune system disorders, multiple sclerosis, hypoxicischemic brain injury and brain tumors. For the complimentary information about various stem cells and their properties we recommend consulting the National Institutes of Health stem cell resources (http://stemcells.nih.gov/info/basics). (Pediatr Res 59: 13R-20R, 2006)
\end{abstract}

\section{EMBRYONIC STEM CELLS (ESCS)}

Isolation. In the mammalian embryo, following fertilization of the egg by a sperm, several cell divisions take place without any growth in total volume, so the cells (now called blastomeres) get progressively smaller. They also rearrange to form a hollow sphere of cells (blastocyst) surrounding a fluid-filled cavity called the blastocoel. The cells of the blastocyst then segregate into an outer layer called the trophectoderm, and an inner cell mass (ICM). The cells of the trophectoderm (trophoblasts) become the fetal contribution to the placenta, while the cells of the ICM give rise to the embryo proper. Around days 5-6 after fertilization in mouse and days 8-9 in humans the cells of the inner mass can be isolated and put in culture. The trophectoderm is removed and the ICM is plated on to a feeder layer of mouse or human embryonic fibroblasts (1), which is essential for the survival of the ICM (2). The ICM then flattens into a compact colony of ESCs, which is than mechanically dissociated and re-plated several times to give rise to stable cell line. It is important to stress that ESCs are an artifact of culturing and differ from the original ICM cells, notably in their pattern of epigenetic modifications. Remarkably, cultured ESCs retain pluripotency and are capable of generating all tissues (including germline) of chimeric mice after the injection into the blastocyst. When the adult chimeric mice have gametes generated from cultured ESCs, breeding of such chimeras will produce an animal composed entirely of the progeny of cultured ESCs. This

Received November 16, 2005; accepted December 21, 2005.

Correspondence: Alexey V. Terskikh, Ph.D., Burnham Institute for Medical Research, 10901 North Torrey Pines Road, La Jolla, CA 92037; e-mail: terskikh@burnham.org A.V.T. and P.H.S. contributed equally to this work.

DOI: 10.1203/01.pdr.0000205154.86517.2a event is called the germline transmission. It is critical to note that ESCs themselves cannot generate the entire embryo.

Properties. Under certain conditions hESC populations can divide almost indefinitely while undifferentiated, but under other conditions they can differentiate into many cell types in the body (2-6). When undifferentiated hESCs are transplanted into an animal, they often form a tumor (teratoma) containing the cells from all three germ layers $(7,8)$. Indeed, the ability of hESCs to form a teratoma after injection is the accepted criterion for identifying hESC lines as such. This is a very crude but necessary test of pluripotency in the absence of the techniques available in mice (blastocyst injection, chimeric mice and germline transmission). As a result, these limitations preclude testing if cultured ESCs are actually capable of generating the entire neuronal diversity of the human brain, for example, as this would require injection of undifferentiated hESCs either into human blastocysts or into the brains of human volunteers, followed by detailed neuroanatomical examination.

When cultured in the laboratory, hESCs grow as compact colonies and usually require the presence of feeder cells for their survival. hESCs can be cloned, albeit at very low efficiency (3). The feeder cells are typically mouse fibroblasts that have been treated with mitotic inhibitors to prevent their proliferation. Human feeder cells can be used as well as feeder-cell conditioned medium, which presumably contains appropriate growth factors (9-11). Recently, bFGF was identified as the factor secreted by fibroblasts to repress serumderived BMP2/4 signaling (100 $\mathrm{ng} / \mathrm{mL}$ bFGF is required) and sustain the undifferentiated proliferation of hESCs in the absence of fibroblasts or conditioned medium (12).

ESCs in culture have a specific morphology, and they express characteristic surface antigens and nuclear transcription factors. The surface antigens include the stage-specific embryonic antigen SSEA-4 and the teratocarcinoma recognition antigens TRA-1-60 and TRA-1-81 (9). The transcription factors include the POU (pit-oct-unc)-domain transcription factor Octamer-4 (Oct-4), associated with the expression of particular elements of the embryonic genome (6). Recently, a new functional marker of the ES cells, NANOG, was discovered simultaneously by two independent teams of investiga-

Abbreviations: BM, bone marrow; ESC, embryonic stem cell; HLA, human leukocyte antigen; HSC, hematopoietic stem cell; ICM, inner cell mass; NSC, neural stem cell; SVZ, sub-ventricular zone 
tors $(13,14)$. Interestingly, NANOG alone can confer the self-renewal and pluripotency to mouse ES cells in the absence of conventional LIF signaling. Moreover, in human ES cells identification of OCT4, SOX2, and NANOG target genes using genome-scale location analysis revealed co-occupancy for a substantial portion of their target genes (15). The above mentioned gene triad together with other modulator genes represent the core transcriptional regulatory circuitry in hES cells.

Differentiation. When undifferentiated hESC colonies are detached from the feeder layer and transferred into serumcontaining medium, they form multi-cellular aggregates called embryoid bodies (EB) which can contain cell types representing all three germ layers of the body: endoderm, mesoderm, and ectoderm. However, the exact composition of each EB is stochastic and unpredictable; therefore, many labs have been trying to develop protocols for directly controlling the differentiation of hESCs.

Exogenous differentiating factors have been useful in favoring differentiation into specific derivatives: retinoic acid and nerve growth factor for neuronal differentiation (16); basic fibroblast growth factor and platelet-derived growth factor for glial precursors (17); 5-aza-2'-deoxycytidine for cardiomyocytes (18); bone morphogenetic protein-4 and transforming growth factor-beta for trophoblasT-cells (19); sodium butyrate for hepatocytes (20); and various cytokines for hematopoietic cells (21). Differentiation into the primitive neural stem cell stage during neural lineage commitment has been proposed to be a default pathway for mouse ES cells (22). In the case of hESCs, culturing of small clusters of pristine pluripotent hESCs in a neurobasal medium supplemented with bFGF and EGF generates a uniform population of human neural precursors (AT, unpublished observation).

Several groups $(17,23-25)$ have produced neuronal precursors from either mouse or human ESCs and tested them by injection into the developing brain of a mouse or rat. The transplanted cells were incorporated into the host brain, migrated along appropriate tracks, differentiated into neurons in a region-specific manner and made synaptic contacts with host neurons. In some cases the transplanted cells also gave rise to glia and astrocytes.

\section{SOMATIC STEM CELLS IN THE ADULT ORGANISM}

Classical embryologists developed the concept that as mammals developed, their cells became progressively more determined for a certain tissue fate and the tissues progressively lost the potential for repair or regeneration. However, recent work has shown that many mammalian tissues including bone marrow, skin, gut lining, blood vessels, endocrine glands, mammary gland, prostate, lung, retina, and parts of the nervous system contain stem cell populations that might selfrenew and generate somatic cells normally as well as mobilize, proliferate and differentiate in response to wounding or disease. The level of self-renewal and degree of differentiation varies drastically between somatic tissues. Almost a quarter of century ago, the realization that custom microenvironments might control hematopoietic stem cells led Schofield (26) to call such regions "niches." A stem cell niche can be defined as a specialized subset of tissue cells and extracellular matrix that harbor one or more somatic stem cells and control their self-renewal and differentiation throughout the life of an organism. Somatic stem/precursor cells from some tissues (e.g. germinal zones in CNS) can be isolated and grown in culture. During in vitro propagation, CNS precursors are said to retain multi-potency, i.e. the ability to differentiate into major cell types appropriate to their original site. It is important to stress that the rigorous definition of pluripotency would require the demonstration that cultured stem/precursor cells are capable of generating the entire variety of cell types of not only the tissue of origin, but other tissues as well.

Hematopoietic stem cells. Since the pioneering experiments of Till and McCulloch (27,28), hematopoietic stem cells (HSCs) are perhaps the most rigorously studied somatic stem cells. The current most-accepted phenotype for the prospective isolation of mouse HSCs (1:5,000 cells) include the $\mathrm{c}-\mathrm{kit}^{+}, \mathrm{ScaI}^{+}, \mathrm{Flk}^{+} /$Thy1.1 ${ }^{\text {low }}, \mathrm{Lin}^{-}$cell population from bone marrow (BM) (29,30). It has been proposed that very primitive pluripotent HSCs are quiescent $(31,32)$. However, while long-term HSCs are normally maintained at constant numbers, these cells do proliferate and increase in number in vivo, for example after reconstitution of lethally-irradiated recipients with a single HSC $(33,34)$. Thus proliferating longterm HSCs must be present in the BM under some circumstances. There is some evidence that c-kit ligand could be crucial for the maintenance of HSCs in the quiescent state within the BM (35).

Another clear example of actively proliferating long-term HSCs is in the fetal liver. In fact, fetal liver HSCs are even more potent in long-term reconstitution assays than adult HSCs (36). Mobilization of HSCs by cyclophosphamide and granulocyte colony-stimulating factor also result in proliferation of HSCs in BM and spleen (37). However, mobilized multi-potent progenitors isolated from the spleen were less efficient than normal BM multi-potent progenitors in engrafting irradiated mice (37).

Several gene products have been proposed to play a role in HSC self-renewal in vitro and in vivo, including activated Notch1 (38), HoxB4 $(39,40)$, thrombopoietin $(18,41,42)$, activated $\beta$-catenin $(43,44)$, FGF-1(45) and Bmi-1 $(46,47)$. However, several issues remain unresolved. While both HoxB4 and FGF-1 were found to act on whole BM, they did not promote the amplification of prospectively isolated HSCs (45). On the other hand, retroviral transformation of HSCs with constitutively active forms of Notch1 and $\beta$-catenin generated cells that were not able to radio-protect recipients and resulted in significant skewing in the reconstituted mice in favor of T-cells and B-cells, respectively $(38,44)$. Currently, no methods can maintain/amplify multi-potent human HSCs in vitro.

Mesenchymal stem cells. In addition to the hematopoietic system, bone marrow also contains a supporting tissue called stroma. It was originally thought to simply provide a structural framework for the hematopoietic system, but it has now been found to contain several cell types with other functions and 
potentials. Most importantly, it contains a population of mesenchymal stem cells (MSCs) (48), which are strongly adherent and can therefore be isolated by culturing marrow on an appropriate substrate and washing other cells off. Mesenchymal stem cells can give rise to many kinds of connective tissue cells including those responsible for remodeling of cartilage, bone, fat, and vascular tissue (49). MSCs are likely to participate in maintenance of the essential microenvironment necessary to support the hematopoietic stem cells in the bone marrow (48).

The results of bone-marrow transplantation studies have led to the conclusion that this remarkable tissue can also produce cells that can circulate to various other sites in the body and contribute to even more tissues including endothelium, muscle, liver, pancreatic islets, heart, brain, lung, kidney, and retina $(50,51)$. A number of studies have claimed an amazing plasticity or trans-differentiation of these bone marrowderived cells (52-58). However, much of this plasticity is clearly the result of cell fusion (59-61). Future rigorous analysis will clarify the extent and the usefulness of transdifferentiation.

Neural stem cells. Cultured neural cells, defined by their clone-forming ability (neurospheres), self-renewal capability and multi-potency, were first isolated from embryonic and adult mice (62). The in vivo origin during development (63) and distribution in the adult (64-67) have since been analyzed in detail. Although still a matter of debate (68), the prevalent model of adult neurogenesis in rodents is based on the results from the laboratory of Alvarez-Buylla (67). The pluripotenTcells in the sub-ventricular zone (SVZ) of the adult rodent brain are thought to be GFAP + cells (called type B-cells) with morphologic characteristic of astrocytes. These cells divide quite rarely and give rise to mitotically active transiently amplifying cells (type $\mathrm{C}$ cells), also located in the subventricular area. In turn, type $\mathrm{C}$ cells give rise to the postmitotic highly migratory neuroblasts (type A cells), which migrate along the rostral migratory stream (RMS) toward the olfactory bulb to generate granule cells and periglomerular interneurons (69). Similar cells have been found in fetal, neonatal, and adult human brain (70,71). However, despite the identification of the unique astrocytic ribbon in human SVZ (72), the phenomenon of massive migration along RMS in adulthood has not been established in humans. Moreover, neurosphere-forming cells from fetal human brain can be prospectively isolated using the marker AC133 (70). Single neural progenitor cells divide and, in the absence of a substrate, gradually grow into balls of 10-10,000 cells called neurospheres. Neural precursor cells migrate out from neurospheres and can give rise to neurons, astrocytes, and oligodendrocytes $(70,71,73)$.

The presence of neural stem cells in the adult brain accounts for the finding of adult neurogenesis, well established in rodents and humans, in many regions of the brain including the SVZ of the anterior lateral ventricles and the dentate gyrus of the hippocampus \{Eriksson, 1998 \#29; Gage, 1998 \#34; Uchida, 2000 \#112; Gage, 2002 \#35; Roy, 2000 \#92; Lu, 2000 \#62; Gould, 1999 \#37; Gould, 1999 \#37\}.

\section{STEM CELL-ASSOCIATED GENES}

Based on expression analysis of neural and hematopoietic stem cells, we have formulated the hypothesis of stem cellassociated genes (74). Transcripts that are enriched in several types of somatic and embryonic stem cells, but downregulated in differentiated cells, may participate in defining the stem cell phenotype and might be involved in basic stem cell functions, such as self-renewal and the ability to regenerate the cellular complexity of a given tissue.

Several following publications put forward the "stemness" hypothesis by forcing the identification of common genes in embryonic, neural and hematopoietic stem cells (75-77). However, very limited overlap between the three independent studies ( 1 common gene) has been raising doubts about the usefulness of such extreme generalization. Indeed, the original suggestion was specifically limited to somatic stem cells and merely suggested to "to test whether these candidates molecules are involved in stem cell self-renewal, differentiation or plasticity" (74). In practice, the "shared" gene pool is enriched in functionally "interesting" genes (e.g., stem cell phenotypes in knock-out animals), thus we consider the stem cellassociated expression as a particular filter to gauge the overwhelming complexity of the microarray analysis datasets.

\section{STEM CELLS, CANCER, CANCER STEM CELLS}

The heterogeneity of human tumors was recognized a long time ago and lead to the idea that only some cells, named cancer stem cells, are capable of initiating the tumor (78). Indeed, such cells have now been identified in several types of tumors such as brain (79), breast (80) and blood (81). Common molecular pathways were suggested to be operational in somatic and cancer stem cells (82). For example, the Bmi1 gene was implicated in self-renewal of somatic stem cells as well as propagation of tumors $(46,83,84)$. Tumor stem cells may also have an epistatic relationship with somatic stem/ precursor cells. Indeed, because neoplastic transformation often requires several consecutive mutations to occur, this is unlikely to happen in the differentiated post-mitotic compartment. On the other hand, the mitotically active stem/precursor cell pool is likely a suitable milieu allowing the accumulation of mutations eventually leading to the transformation.

\section{STEM CELL THERAPIES}

Blood and immune system disorders. Transplantation of bone marrow, containing HSCs or purified cell fractions from bone marrow, has been used for over three decades in the treatment of disorders of the blood-cell production system. Children with Severe Combined Immune Deficiency have been successfully treated by bone marrow transplantation since 1968 (85). Leukemia patients have been successfully treated with chemotherapy to destroy the bone marrow followed by rescue with bone-marrow transplants from HLAidentical twins or siblings or HLA-matched donors (85). For lymphoma and leukemia, the patient's own bone marrow may be harvested in advance when the disease is in remission, cleared of undesirable cells (residual malignant cells, and cells 
that could mediate a graft-versus-host immune reaction), and frozen so that it can subsequently be used to restore the patient's hematopoietic system after chemotherapy. More recently, peripheral blood (after treatment of the donor with cytokines to mobilize stem cells) has been found to be a better source of stem cells to restore hematopoiesis (85). Umbilical cord blood (UCB) can also be used and has several advantages over bone marrow as a source of HSCs, especially in pediatric patients (86). In principle, the HSCs are the only cells required to restore the ablated hematopoietic system. As a proof of principle, the transplantation of extensively purified mobilized peripheral blood $\mathrm{CD} 34^{+}$, Thy- ${ }^{+}$HSCs, used as the sole source of the hematopoietic graft from 22 patients with recurrent or metastatic breast cancer, resulted in rapid and sustained hematopoietic engraftment (87).

Metabolic diseases. Another group of diseases being treated with HSC transplantation is the lysosomal storage disorders, including the mucopolysaccharidoses such as Hurler's Syndrome. These diseases involve the harmful accumulation of specific cell components, due to the absence or inactivity of a specific enzyme normally involved in their degradation. In these cases, stem cell therapy would function primarily for enzyme replacement, by providing cells containing an active form of the missing or defective enzyme. Since disease progression may lead to extensive damage, early diagnosis and treatment is essential (88). At present, HSC transplantation is effective primarily for soft-tissue, non-central nervous system organs such as spleen and liver, with only limited effectiveness for bone and cartilage, and little to no effectiveness for the CNS (88).

\section{EXPERIMENTAL THERAPEUTIC APPLICATIONS}

Autoimmune diseases/multiple sclerosis (MS). Multiple Sclerosis (MS) is a debilitating neurologic disease in which chronic inflammation of the CNS leads to multiple impairments of motor, sensory, and cognitive functions. It affects about a million people worldwide, about 200,000 of them in the U.S. The fundamental feature of the disorder is that the individual's own immune system attacks and destroys the myelin sheath that normally surrounds nerve fibers. Some of the destroyed myelin regenerates spontaneously, although it is not clear exactly which cell type is responsible for producing this myelin. Current treatments mainly use the immunomodulator $\beta$-interferon to slow the progression of the disease.

Two different manipulations of stem-cell populations are being tested as potential treatments for MS. First, since the disease results mainly from the development of a population of immune cells that attack the myelin sheaths of neurons, the replacement of the stem cell population generating these immune cells is a logical goal. In fact, the possibility of this kind of treatment was first recognized when some MS patients being treated by transplants of blood stem cells for other diseases showed remission of their MS symptoms. In a clinical trial of hematopoietic stem-cell (HSC) transplantation for MS, 20 out of 26 patients appeared to stabilize (84). These trials included a combination of total body irradiation and chemotherapy followed by peripheral blood stem cell transplanta- tion. About 250 patients are currently in Phase I and Phase II open clinical trials (89).

Soon after their discovery, neural stem cells (NSCs) were recognized as having tremendous potential for the cell-based repair of neurological damage (90). However, it seems likely that the first applications will be for therapy of neurological diseases that do not require the establishment of new neuronal circuitry, notably MS (91-93), Parkinson's disease (94), and metabolic diseases. Thus, NSC therapy could be used to repair the de-myelination caused by the immune attack. NSCs support the production of neurons and glia in parts of the normal brain throughout adulthood. They can be isolated from either fetal or adult brains, expanded extensively and maintained safely in a chemically-defined medium; they can be directed into a neuronal fate or an astrocyte fate by treatment with different growth factors; and they can be safely frozen and thawed, thus eliminating the need for continuous maintenance $(95,96)$. Their ability to migrate over long distances in the body and to apparently home in on diseased areas also makes them uniquely suitable for cell therapy of diseases, including MS, that are multi-focal (affecting many locations in the body) (97).

In a mouse model of MS, NSCs implanted into the brain survived well, could home in on the de-myelinated region, differentiate into oligodendrocytes, stimulate the increased production of host oligodendrocytes and re-myelinate the damaged fibers. They also reduced astrogliosis, further demyelination and axon loss (91). These cells were equally effective if administered via the circulation, after which they passed through the blood-brain barrier and entered the brain. Many of the treated mice were completely cured of the disease, and the cells did not produce tumors.

Embryonic stem cells (ESCs) are also an attractive option for treatment of demyelinating diseases. When transplanted into rodents suffering from demyelinating disease, they can differentiate into glial cells and remyelinate affected axons $(17,98,99)$. However, these cells also produce teratomas (100) so the controls over their differentiation will have to be analyzed more thoroughly before they can be seriously considered for use in stem-cell therapy. It has already been shown that ESCs can be induced to differentiate into oligodendrocyte precursors, and that these can be used to promote myelination of axons in the shiverer mouse (101), which suffers from defective myelination.

The remarkable ability of stem cells to home in on diseased areas appears to be a response to the inflammation at the disease site. Inflammation involves the production of a wellcharacterized set of molecules including proteins that function in adhesion between cells (e.g. integrins), proteins that act as signals between cells to attract them to each other and to activate them in various ways (chemokines and cytokines), and specific receptors for these proteins $(102,103)$. An intriguing discovery regarding the mechanism was that two proteins (CD44 and Very Late Antigen-4), shown to be required for NSCs to home in on inflamed regions, are the same proteins that attracted the inflammatory lymphocytes to the site in the first place (93). 


\section{POTENTIAL THERAPEUTIC APPLICATIONS}

Hypoxic-ischemic brain injury. Neonatal hypoxiaischemia is a major contributor to chronic neurologic dysfunction (104-106). A clinically relevant rat model was established in neonatal rats by Vannucci and colleagues (107) and then adapted for mice (108-111). Neonatal hypoxic-ischemic injury has been shown to increase cell proliferation and neurogenesis in the SVZ and peri-infarct striatum, and to directly correlate with the degree of damage (112). BrdU, doublecortin and Map2 labeling identified extensive migration of newborn neuroblasts and terminally differentiated NeuN-positive neurons. Mature newborn astrocytes and oligodendrocytes were also detected $2 \mathrm{wk}$ after injury. However, few newly generated cells were found $3 \mathrm{wk}$ after injury, implying that the endogenous precursors failed to survive and differentiate (112). The neonatal hypoxia-ischemia model has neuronal destruction in the same brain regions as in adult animals, but also causes necrosis of white matter, which is linked to oligodendrocyte precursor death and disrupted myelin production (110). Thus, this model can be used to assay both neurogenic and oligodendrogenic/myelination potential of the transplanted neural precursors.

Metabolic diseases affecting the brain. As mentioned above, HSC therapy for metabolic diseases has had some, but limited success (88). This limit is particularly true for the CNS. In animal models of some of the lysosomal storage disorders, however, implantation of NSCs into the brain significantly ameliorates the detrimental effects of the disease on the brain $(113,114)$. These data suggest that combination stem cell therapy, using HSCs for the periphery and NSCs for the brain, might be a much more effective treatment strategy for these patients. In addition, transplantation of another stem cell component of bone marrow, the mesenchymal stem cells, may be beneficial for the bone and cartilage defects found in these diseases (115).

Brain tumors. NSCs have a remarkable ability to migrate through the body and through normal tissues to accumulate in various types of tumors, both neural and non-neural (116). This provides a potential avenue to developing radically new types of cancer treatment, especially for tumors that infiltrate the brain so extensively that they cannot be effectively removed by surgery or chemotherapy. In such cases, it may be possible to use the homing ability of NSCs to deliver chemotherapeutic agents accurately and exclusively to the tumor cells.

In studies on an experimentally-induced glioma in mice, NSCs were implanted either into the tumor or at sites within the brain but distant from the tumor. When implanted directly into the tumor, they spread through the tumor, and when they were implanted into other sites in the brain they migrated to the tumor and spread through it (117). Even when they are delivered simply by injection into the circulation, NSCs can also target both brain tumors and tumors at other sites including prostate cancer and malignant melanoma, without significant accumulation in normal tissues (117). In addition, NSCs have been genetically engineered to produce various products that could be delivered directly to the tumor (118). They can be designed to release cytolytic viruses that destroy adjacent cells, to produce anti-tumor proteins, or to secrete enzymes that will locally convert inactive pro-drugs into active chemotherapeutic compounds (119). NSCs may also contribute to recovery of tissues damaged by cancer. They may differentiate directly into neurons and other damaged cell types, but they may also promote the ability of host cells to replace diseased tissue, especially if they are genetically engineered to produce appropriate neurotrophic factors. NSCs that are engineered as therapeutic agents can also be specially tagged so that they can be monitored in vivo after injection (120).

\section{AVOIDING OR OVERCOMING IMMUNE REJECTION IN STEM CELL TRANSPLANTATION}

Even though HLA matching remains the single most effective method for minimizing immune rejection, it is anticipated that the use of stem cells from donors will require the same kind of immunosuppression that is being used with other organ transplant therapies. This is clearly true for HSCs and presumably will also be true for other adult stem cells. However, ESCs may not elicit the same kind of immune response that is associated with transplantation of more mature cells or tissues. Injection of ESCs into immune-competent mice failed to induce an immune response (121), suggesting that any ESC line may be immunologically compatible with any recipient, obviating the need for either therapeutic cloning or a large ESC bank. These studies, however, must be replicated and expanded to include specific differentiated cell types.

The ideal solution to the potential problems of immune rejection of transplanted stem cells would be to generate stem cells that are genetically identical to the patient. In principle, this can be done by replacing the nucleus of a donor stem cell with a nucleus from a somatic (body) cell of the patient, and growing up the resulting cell into a new stem cell line, which hopefully would retain its stem-cell properties and could be used in stem cell therapy. This process of somatic cell nuclear transfer has been proven in animal models (122) and tested with human cells by researchers (123) who showed that the resulting ESCs retained stem-cell characteristics, including expression of several stem-cell specific markers, differentiation in vitro and in vivo into all three germ layers, and continuous proliferation.

\section{SCIENTIFIC ISSUES ARISING IN STEM CELL THERAPY}

Use of animal cells or products. Feeder cells from other mammals have often been used for the culture of ESCs, and this may limit the use of the stem cells in therapy according to current FDA regulations (124). However, this regulatory hurdle can be cleared by demonstrating that the ESCs grown on non-human feeder cells do not carry non-human (or human) pathogens (viruses, bacteria). In addition, it has recently been shown that ESCs cultured in the absence of animal cells but in the presence of animal-cell-derived products may show the presence of animal-specific molecules (125). Although it has been suggested that this may obviate the use of the cells for therapeutic applications, the clinical use of similarly-treated 
cells or other implantable products has been underway for many years (FDA Xenotransplantation Action Plan). In addition, it is possible to significantly reduce the animal components simply by culture of the cells in non-animal based systems (125).

Tumor-forming potential of ESCS. One of the basic properties of undifferentiated ESCs is their ability to form a teratoma. Implantation of this type of cell, therefore, carries substantial risk (126). Undifferentiated ESCs are thus unlikely to be used directly in therapeutic applications. Differentiation of an ESC eliminates its capacity to form a tumor. Thus, ESCs will be used to generate lines of cells that are at least partially differentiated, and these derived cell lines will be used therapeutically (127).

\section{REFERENCES}

1. Thomson JA, Itskovitz-Eldor J, Shapiro SS, Waknitz MA, Swiergiel JJ, Marshall VS, Jones JM 1998 Embryonic stem cell lines derived from human blastocysts. Science 282:1145-1147

2. Cowan CA, Klimanskaya I, McMahon J, Atienza J, Witmyer J, Zucker JP, Wang S, Morton CC, McMahon AP, Powers D, Melton DA 2004 Derivation of embryonic stem-cell lines from human blastocysts. N Engl J Med 350:1353-1356

3. Amit M, Carpenter MK, Inokuma MS, Chiu CP, Harris CP, Waknitz MA, Itskovitz-Eldor J, Thomson JA 2000 Clonally derived human embryonic stem cell lines maintain pluripotency and proliferative potential for prolonged periods of culture. Dev Biol 227:271-278

4. Bodnar MS, Meneses JJ, Rodriguez RT, Firpo MT 2004 Propagation and maintenance of undifferentiated human embryonic stem cells. Stem Cells Dev 13:243-253

5. Odorico JS, Kaufman DS, Thomson JA 2001 Multilineage differentiation from human embryonic stem cell lines. Stem Cells 19:193-204

6. Thomson JA, Itskovitz-Eldor J, Shapiro SS, Waknitz MA, Swiergiel JJ, Marshall VS, Jones JM 1998 Embryonic stem cell lines derived from human blastocysts. Science 282:1145-1147

7. Ruiz i Altaba A, Sanchez P, Dahmane N 2002 Gli and hedgehog in cancer: tumours, embryos and stem cells. Nat Rev Cancer 2:361-372

8. Trounson A 2004 Stem cells, plasticity and cancer - uncomfortable bed fellows. Development 131:2763-2768

9. Carpenter MK, Rosler ES, Fisk GJ, Brandenberger R, Ares X, Miura T, Lucero M, Rao MS 2004 Properties of four human embryonic stem cell lines maintained in a feeder-free culture system. Dev Dyn 229:243-258

10. Rosler ES, Fisk GJ, Ares X, Irving J, Miura T, Rao MS, Carpenter MK 2004 Long-term culture of human embryonic stem cells in feeder-free conditions. Dev Dyn 229:259-274

11. Xu C, Inokuma MS, Denham J, Golds K, Kundu P, Gold JD, Carpenter MK 2001 Feeder-free growth of undifferentiated human embryonic stem cells. Nat Biotechnol 19:971-974

12. Xu RH, Peck RM, Li DS, Feng X, Ludwig T, Thomson JA 2005 Basic FGF and suppression of BMP signaling sustain undifferentiated proliferation of human ES cells. Nat Methods 2:185-190

13. Mitsui K, Tokuzawa Y, Itoh H, Segawa K, Murakami M, Takahashi K, Maruyama M, Maeda M, Yamanaka S 2003 The homeoprotein Nanog is required for maintenance of pluripotency in mouse epiblast and ES cells. Cell 113:631-642

14. Chambers I, Colby D, Robertson M, Nichols J, Lee S, Tweedie S, Smith A 2003 Functional expression cloning of Nanog, a pluripotency sustaining factor in embryonic stem cells. Cell 113:643-655

15. Boyer LA, Lee TI, Cole MF, Johnstone SE, Levine SS, Zucker JP, Guenther MG, Kumar RM, Murray HL, Jenner RG, Gifford DK, Melton DA, Jaenisch R, Young RA 2005 Core transcriptional regulatory circuitry in human embryonic stem cells. Cell 122:947-956

16. Schuldiner M, Eiges R, Eden A, Yanuka O, Itskovitz-Eldor J, Goldstein RS, Benvenisty N 2001 Induced neuronal differentiation of human embryonic stem cells. Brain Res 913:201-205

17. Brustle O, Jones KN, Learish RD, Karram K, Choudhary K, Wiestler OD, Duncan ID, McKay RD 1999 Embryonic stem cell-derived glial precursors: a source of myelinating transplants. Science 285:754-756

18. Xu C, Police S, Rao N, Carpenter MK 2002 Characterization and enrichment of cardiomyocytes derived from human embryonic stem cells. Circ Res 20; 91:501508

19. Carpenter MK, Rosler E, Rao MS 2003 Characterization and differentiation of human embryonic stem cells. Cloning Stem Cells 5:79-88

20. Rambhatla L, Chiu CP, Kundu P, Peng Y, Carpenter MK 2003 Generation of hepatocyte-like cells from human embryonic stem cells. Cell Transplant 12:1-11

21. Zhan X, Dravid G, Ye Z, Hammond H, Shamblott M, Gearhart J, Cheng L 2004 Functional antigen-presenting leucocytes derived from human embryonic stem cells in vitro. Lancet 364:163-171

22. Tropepe V, Hitoshi S, Sirard C, Mak TW, Rossant J, van der Kooy D 2001 Direct neural fate specification from embryonic stem cells: a primitive mammalian neural stem cell stage acquired through a default mechanism. Neuron 30:65-78
23. Reubinoff BE, Itsykson P, Turetsky T, Pera MF, Reinhartz E, Itzik A, Ben-Hur T 2001 Neural progenitors from human embryonic stem cells. Nat Biotechnol 19:1134-1140

24. Wernig M, Benninger F, Schmandt T, Rade M, Tucker KL, Bussow H, Beck H, Brustle O 2004 Functional integration of embryonic stem cell-derived neurons in vivo. J Neurosci 24:5258-5268

25. Tabar V, Panagiotakos G, Greenberg ED, Chan BK, Sadelain M, Gutin PH, Studer L 2005 Migration and differentiation of neural precursors derived from human embryonic stem cells in the rat brain. Nat Biotechnol 23:601-606

26. Schofield R 1978 The relationship between the spleen colony-forming cell and the haemopoietic stem cell. Blood Cells 4:7-25

27. Till JE, McCulloch EA, Siminovitch L 1964 A stochastic model of stem cell proliferation, based on the growth of spleen colony-forming cells. Proc Natl Acad Sci U S A 51:29-36

28. Till JE, Mc CE 1961 A direct measurement of the radiation sensitivity of normal mouse bone marrow cells. Radiat Res 14:213-222

29. Morrison SJ, Weissman IL 1994 The long-term repopulating subset of hematopoietic stem cells is deterministic and isolatable by phenotype. Immunity 1:661-673

30. Christensen JL, Weissman IL 2001 Flk-2 is a marker in hematopoietic stem cell differentiation: a simple method to isolate long-term stem cells. Proc Natl Acad Sci U S A 98:14541-14546

31. Lanzkron SM, Collector MI, Sharkis SJ 1999 Hematopoietic stem cell tracking in vivo: a comparison of short-term and long-term repopulating cells. Blood 93:19161921

32. Brown AB, Yang W, Schmidt NO, Carroll R, Leishear KK, Rainov NG, Black PM, Breakefield XO, Aboody KS 2003 Intravascular delivery of neural stem cell lines to target intracranial and extracranial tumors of neural and non-neural origin. Hum Gene Ther 14:1777-1785

33. Osawa M, Hanada K, Hamada H, Nakauchi H 1996 Long-term lymphohematopoietic reconstitution by a single CD34- low/negative hematopoietic stem cell. Science 273:242-245

34. Wagers AJ, Sherwood RI, Christensen JL, Weissman IL 2002 Little evidence for developmental plasticity of adult hematopoietic stem cells. Science 297:2256-2259

35. Heissig B, Hattori K, Dias S, Friedrich M, Ferris B, Hackett NR, Crystal RG, Besmer P, Lyden D, Moore MA, Werb Z, Rafii S 2002 Recruitment of stem and progenitor cells from the bone marrow niche requires MMP-9 mediated release of kit-ligand. Cell 109:625-637

36. Morrison SJ, Hemmati HD, Wandycz AM, Weissman IL 1995 The purification and characterization of fetal liver hematopoietic stem cells. Proc Natl Acad Sci U S A 92:10302-10306

37. Morrison SJ, Wright DE, Weissman IL 1997 Cyclophosphamide/granulocyte colony-stimulating factor induces hematopoietic stem cells to proliferate prior to mobilization. Proc Natl Acad Sci U S A 94:1908-1913

38. Varnum-Finney B, Xu L, Brashem-Stein C, Nourigat C, Flowers D, Bakkour S, Pear WS, Bernstein ID 2000 Pluripotent, cytokine-dependent, hematopoietic stem cells are immortalized by constitutive Notch1 signaling. Nat.Med 6:1278-1281

39. Sauvageau G, Thorsteinsdottir U, Eaves CJ, Lawrence HJ, Largman C, Lansdorp PM, Humphries RK 1995 Overexpression of HOXB4 in hematopoietic cells causes the selective expansion of more primitive populations in vitro and in vivo. Genes Dev 9:1753-1765

40. Antonchuk J, Sauvageau G, Humphries RK 2002 HOXB4-induced expansion of adult hematopoietic stem cells ex vivo. Cell 109:39-45

41. Sitnicka E, Lin N, Priestley GV, Fox N, Broudy VC, Wolf NS, Kaushansky K 1996 The effect of thrombopoietin on the proliferation and differentiation of murine hematopoietic stem cells. Blood 87:4998-5005

42. Richard RE, Wood B, Zeng H, Jin L, Papayannopoulou T, Blau CA 2000 Expansion of genetically modified primary human hemopoietic cells using chemical inducers of dimerization. Blood 95:430-436

43. Willert K, Brown JD, Danenberg E, Duncan AW, Weissman IL, Reya T, Yates JR 3rd, Nusse R 2003 Wnt proteins are lipid-modified and can act as stem cell growth factors. Nature 423:448-452

44. Reya T, Duncan AW, Ailles L, Domen J, Scherer DC, Willert K, Hintz L, Nusse R, Weissman IL 2003 A role for Wnt signalling in self-renewal of haematopoietic stem cells. Nature 423:409-414

45. de Haan G, Weersing E, Dontje B, van Os R, Bystrykh LV, Vellenga E, Miller G 2003 In vitro generation of long-term repopulating hematopoietic stem cells by fibroblast growth factor-1. Dev Cell 4:241-251

46. Lessard J, Sauvageau G 2003 Bmi-1 determines the proliferative capacity of normal and leukaemic stem cells. Nature 423:255-260

47. Park IK, Qian D, Kiel M, Becker MW, Pihalja M, Weissman IL, Morrison SJ, Clarke MF 2003 Bmi-1 is required for maintenance of adult self-renewing haematopoietic stem cells. Nature 423:302-305

48. Dennis JE, Caplan AI 2004 Bone Marrow Mesenchymal Stem Cells. In: Sell S (ed) Stem Cells Handbook. Humana Press, Totowa, pp 107-118.

49. Pittenger MF, Mackay AM, Beck SC, Jaiswal RK, Douglas R, Mosca JD, Moorman MA, Simonetti DW, Craig S, Marshak DR 1999 Multilineage potential of adult human mesenchymal stem cells. Science 284:143-147

50. Huttmann A, Li CL, Duhrsen U 2003 Bone marrow-derived stem cells and "plasticity". Ann Hematol 82:599-604

51. Sell S 2004 Stem Cells: What Are They? Where Do They Come From? Why Are They Here? When Do They Go Wrong? Where Are They Going? In: Sell S (ed) Stem Cells Handbook. Humana Press, Totowa, pp 1-18.

52. Mezey E, Key S, Vogelsang G, Szalayova I, Lange GD, Crain B 2003 Transplanted bone marrow generates new neurons in human brains. Proc Natl Acad Sci U S A 100:1364-1369 
53. Theise ND, Nimmakayalu M, Gardner R, Illei PB, Morgan G, Teperman L, Henegariu O, Krause DS 2000 Liver from bone marrow in humans. Hepatology 32:11-16

54. Thiele J, Varus E, Wickenhauser C, Kvasnicka HM, Metz K, Schaefer UW, Beelen DW 2002 [Chimerism of cardiomyocytes and endothelial cells after allogeneic bone marrow transplantation in chronic myeloid leukemia. An autopsy study]. Pathologe 23:405-410

55. Gussoni E, Soneoka Y, Strickland CD, Buzney EA, Khan MK, Flint AF, Kunkel LM, Mulligan RC 1999 Dystrophin expression in the mdx mouse restored by stem cell transplantation. Nature 401:390-394

56. Orlic D, Kajstura J, Chimenti S, Jakoniuk I, Anderson SM, Li B, Pickel J, McKay R, Nadal-Ginard B, Bodine DM, Leri A, Anversa P 2001 Bone marrow cells regenerate infarcted myocardium. Nature 410:701-705

57. Lagasse E, Connors H, Al Dhalimy M, Reitsma M, Dohse M, Osborne L, Wang X, Finegold M, Weissman IL, Grompe M 2000 Purified hematopoietic stem cells can differentiate into hepatocytes in vivo. Nat Med 6:1229-1234

58. Petersen BE, Bowen WC, Patrene KD, Mars WM, Sullivan AK, Murase N, Boggs SS, Greenberger JS, Goff JP 1999 Bone marrow as a potential source of hepatic oval cells. Science 284:1168-1170

59. Ying QL, Nichols J, Evans EP, Smith AG 2002 Changing potency by spontaneous fusion. Nature 416:545-548

60. Alvarez-Dolado M, Pardal R, Garcia-Verdugo JM, Fike JR, Lee HO, Pfeffer K, Lois C, Morrison SJ, Alvarez-Buylla A 2003 Fusion of bone-marrow-derived cells with Purkinje neurons, cardiomyocytes and hepatocytes. Nature 425:968-973

61. Wang X, Willenbring H, Akkari Y, Torimaru Y, Foster M, Al Dhalimy M, Lagasse E, Finegold M, Olson S, Grompe M 2003 Cell fusion is the principal source of bone-marrow-derived hepatocytes. Nature 422:897-901

62. Reynolds BA, Weiss S 1996 Clonal and population analyses demonstrate that an EGF-responsive mammalian embryonic CNS precursor is a stem cell. Dev Biol 175:1-13

63. Temple S 2001 The development of neural stem cells. Nature 414:112-117

64. Garcia-Verdugo JM, Doetsch F, Wichterle H, Lim DA, Alvarez-Buylla A 1998 Architecture and cell types of the adult sub-ventricular zone: in search of the stem cells. J Neurobiol 36:234-248

65. Alvarez-Buylla A, Seri B, Doetsch F 2002 Identification of neural stem cells in the adult vertebrate brain. Brain Res Bull 57:751-758

66. Doetsch F, Caille I, Lim DA, Garcia-Verdugo JM, Alvarez-Buylla A 1999 Subventricular zone astrocytes are neural stem cells in the adult mammalian brain. Cell 97:703-716

67. Doetsch F 2003 A niche for adult neural stem cells. Curr Opin Genet Dev 13:543-550

68. Johansson CB, Svensson M, Wallstedt L, Janson AM, Frisen J 1999 Neural stem cells in the adult human brain. Exp Cell Res 253:733-736

69. Petreanu L, Alvarez-Buylla A 2002 Maturation and death of adult-born olfactory bulb granule neurons: role of olfaction. J Neurosci 22:6106-6113

70. Uchida N, Buck DW, He D, Reitsma MJ, Masek M, Phan TV, Tsukamoto AS, Gage FH, Weissman IL 2000 Direct isolation of human central nervous system stem cells. Proc Natl Acad Sci U S A 97:14720-14725

71. Palmer TD, Schwartz PH, Taupin P, Kaspar B, Stein SA, Gage FH 2001 Cell culture. Progenitor cells from human brain after death. Nature 411:42-43

72. Sanai N, Tramontin AD, Quinones-Hinojosa A, Barbaro NM, Gupta N, Kunwar S, Lawton MT, McDermott MW, Parsa AT, Manuel-Garcia Verdugo J, Berger MS, Alvarez-Buylla A 2004 Unique astrocyte ribbon in adult human brain contains neural stem cells but lacks chain migration. Nature 427:740-744

73. Schwartz PH, Bryant PJ, Fuja TJ, Su H, O'Dowd DK, Klassen H 2003 Isolation and characterization of neural progenitor cells from post-mortem human cortex. J Neurosci Res 74:838-851

74. Terskikh AV, Easterday MC, Li L, Hood L, Kornblum HI, Geschwind DH, Weissman IL 2001 From hematopoiesis to neuropoiesis. evidence of overlapping genetic programs. Proc Natl Acad Sci U S A 98:7934-7939

75. Ivanova NB, Dimos JT, Schaniel C, Hackney JA, Moore KA, Lemischka IR 2002 A stem cell molecular signature. Science 298:601-604

76. Ramalho-Santos M, Yoon S, Matsuzaki Y, Mulligan RC, Melton DA 2002 "Stemness": transcriptional profiling of embryonic and adult stem cells. Science 298:597-600

77. Fortunel NO, Otu HH, Ng HH, Chen J, Mu X, Chevassut T, Li X, Joseph M, Bailey C, Hatzfeld JA, Hatzfeld A, Usta F, Vega VB, Long PM, Libermann TA, Lim B 2003 Comment on "'Stemness': transcriptional profiling of embryonic and adult stem cells" and "a stem cell molecular signature". Science 302:393

78. Hager JC, Heppner GH 1983 Breast cancer stem cells. Prog Clin Biol Res 132C:137-146

79. Singh SK, Clarke ID, Terasaki M, Bonn VE, Hawkins C, Squire J, Dirks PB 2003 Identification of a cancer stem cell in human brain tumors. Cancer Res 63:58215828

80. Al-Hajj M, Wicha MS, Benito-Hernandez A, Morrison SJ, Clarke MF 2003 Prospective identification of tumorigenic breast cancer cells. Proc Natl Acad Sci USA 100:3983-3988

81. Warner JK, Wang JC, Hope KJ, Jin L, Dick JE 2004 Concepts of human leukemic development. Oncogene 23:7164-7177

82. Reya T, Morrison SJ, Clarke MF, Weissman IL 2001 Stem cells, cancer, and cancer stem cells. Nature 414:105-111

83. Molofsky AV, Pardal R, Iwashita T, Park IK, Clarke MF, Morrison SJ 2003 Bmi-1 dependence distinguishes neural stem cell self-renewal from progenitor proliferation. Nature 425:962-967
84. Nash RA, Bowen JD, McSweeney PA, Pavletic SZ, Maravilla KR, Park MS, Storek J, Sullivan KM, Al Omaishi J, Corboy JR, DiPersio J, Georges GE, Gooley TA, Holmberg LA, LeMaistre CF, Ryan K, Openshaw H, Sunderhaus J, Storb R, Zunt J, Kraft GH 2003 High-dose immunosuppressive therapy and autologous peripheral blood stem cell transplantation for severe multiple sclerosis. Blood 102:2364-2372

85. Baird SM 2004 Hematopoietic Stem Cells in Leukemia and Lymphoma. In: Sell S (ed) Stem Cells Handbook. Humana Press, Totowa, pp 163-176.

86. Lewis ID 2002 Clinical and experimental uses of umbilical cord blood. Intern Med J 32:601-609

87. Negrin RS, Atkinson K, Leemhuis T, Hanania E, Juttner C, Tierney K, Hu WW, Johnston LJ, Shizurn JA, Stockerl-Goldstein KE, Blume KG, Weissman IL, Bowe S, Baynes R, Dansey R, Karanes C, Peters W, Klein J 2000 Transplantation of highly purified CD34+Thy-1+ hematopoietic stem cells in patients with metastatic breast cancer. Biol.Blood Marrow Transplant 6:262-271

88. Malatack JJ, Consolini DM, Bayever E 2003 The status of hematopoietic stem cell transplantation in lysosomal storage disease. Pediatr Neurol 29:391-403

89. Sykes M, Nikolic B 2005 Treatment of severe autoimmune disease by stem-cell transplantation. Nature 435:620-627

90. Rice CM, Halfpenny CA, Scolding NJ 2003 Stem cells for the treatment of neurological disease. Transfus Med 13:351-361

91. Pluchino S, Quattrini A, Brambilla E, Gritti A, Salani G, Dina G, Galli R, Del Carro U, Amadio S, Bergami A, Furlan R, Comi G, Vescovi AL, Martino G 2003 Injection of adult neurospheres induces recovery in a chronic model of multiple sclerosis. Nature 422:688-694

92. Furlan R, Pluchino S, Martino G 2003 The therapeutic use of gene therapy in inflammatory demyelinating diseases of the central nervous system. Curr Opin Neurol 16:385-392

93. Pluchino S, Furlan R, Martino G 2004 Cell-based remyelinating therapies in multiple sclerosis: evidence from experimental studies. Curr Opin Neurol 17:247255

94. Drucker-Colin R, Verdugo-Diaz L 2004 Cell transplantation for Parkinson's disease: present status. Cell Mol Neurobiol 24:301-316

95. Vescovi AL, Parati EA, Gritti A, Poulin P, Ferrario M, Wanke E, FrolichsthalSchoeller P, Cova L, Arcellana-Panlilio M, Colombo A, Galli R 1999 Isolation and cloning of multi-potential stem cells from the embryonic human CNS and establishment of transplantable human neural stem cell lines by epigenetic stimulation. Exp Neurol 156:71-83

96. Nunes MC, Roy NS, Keyoung HM, Goodman RR, McKhann G 2nd, Jiang L, Kang J, Nedergaard M, Goldman SA 2003 Identification and isolation of multi-potential neural progenitor cells from the subcortical white matter of the adult human brain. Nat Med 9:439-447

97. Imitola J, Raddassi K, Park KI, Mueller FJ, Nieto M, Teng YD, Frenkel D, Li J, Sidman RL, Walsh CA, Snyder EY, Khoury SJ 2004 Directed migration of neural stem cells to sites of CNS injury by the stromal cell-derived factor 1alpha/CXC chemokine receptor 4 pathway. Proc Natl Acad Sci U S A 101:18117-18122

98. Liu S, Qu Y, Stewart TJ, Howard MJ, Chakrabortty S, Holekamp TF, McDonald JW 2000 Embryonic stem cells differentiate into oligodendrocytes and myelinate in culture and after spinal cord transplantation. Proc Natl Acad Sci U S A 97:61266131

99. McDonald JW, Liu XZ, Qu Y, Liu S, Mickey SK, Turetsky D, Gottlieb DI, Choi DW 1999 Transplanted embryonic stem cells survive, differentiate and promote recovery in injured rat spinal cord. Nat Med 5:1410-1412

100. Brustle O, Spiro AC, Karram K, Choudhary K, Okabe S, McKay RD 1997 In vitro-generated neural precursors participate in mammalian brain development. Proc Natl Acad Sci U S A 94:14809-14814

101. Nistor GI, Totoiu MO, Haque N, Carpenter MK, Keirstead HS 2005 Human embryonic stem cells differentiate into oligodendrocytes in high purity and myelinate after spinal cord transplantation. Glia 49:385-396

02. Cottler-Fox MH, Lapidot T, Petit I, Kollet O, DiPersio JF, Link D, Devine S 2003 Stem cell mobilization. Hematology (Am Soc Hematol Educ Program), pp 419437.

103. Lapidot T, Petit I 2002 Current understanding of stem cell mobilization: the roles of chemokines, proteolytic enzymes, adhesion molecules, cytokines, and stromal cells. Exp Hematol 30:973-981

104. Volpe JJ 1997 Brain injury in the premature infant. Neuropathology, clinical aspects, pathogenesis, and prevention. Clin Perinatol 24:567-587

105. Volpe JJ 1998 Brain injury in the premature infant: overview of clinical aspects, neuropathology, and pathogenesis. Semin Pediatr Neurol 5:135-151

106. Volpe JJ 1998 Neurologic outcome of prematurity. Arch Neurol 55:297-300

107. Rice JE 3rd, Vannucci RC, Brierley JB 1981 The influence of immaturity on hypoxic-ischemic brain damage in the rat. Ann Neurol 9:131-141

108. Sheldon RA, Sedik C, Ferriero DM 1998 Strain-related brain injury in neonatal mice subjected to hypoxia ischemia. Brain Res 810:114-122

109. Connolly ES Jr., Winfree CJ, Stern DM, Solomon RA, Pinsky DJ 1996 Procedural and strain-related variables significantly affect outcome in a murine model of focal cerebral ischemia. Neurosurgery 38:523-531; discussion 532 .

110. Skoff RP, Bessert DA, Barks JD, Song D, Cerghet M, Silverstein FS 2001 Hypoxic-ischemic injury results in acute disruption of myelin gene expression and death of oligodendroglial precursors in neonatal mice. Int J Dev Neurosci 19:197208

111. Zaidi AU, Bessert DA, Ong JE, Xu H, Barks JD, Silverstein FS, Skoff RP 2004 New oligodendrocytes are generated after neonatal hypoxic-ischemic brain injury in rodents. Glia 46:380-390

112. Plane JM, Liu R, Wang TW, Silverstein FS, Parent JM 2004 Neonatal hypoxicischemic injury increases forebrain sub-ventricular zone neurogenesis in the mouse. Neurobiol Dis 16:585-595 
113. Eto Y, Shen JS, Meng XL, Ohashi T 2004 Treatment of lysosomal storage disorders: cell therapy and gene therapy. J Inherit Metab Dis 27:411-415

114. Shihabuddin LS, Numan S, Huff MR, Dodge JC, Clarke J, Macauley SL, Yang W, Taksir TV, Parsons G, Passini MA, Gage FH, Stewart GR 2004 Intracerebral transplantation of adult mouse neural progenitor cells into the Niemann-Pick-A Mouse leads to a marked decrease in lysosomal storage pathology. J Neurosci 24:10642-10651

115. Koc ON, Day J, Nieder M, Gerson SL, Lazarus HM, Krivit W 2002 Allogeneic mesenchymal stem cell infusion for treatment of metachromatic leukodystrophy (MLD) and Hurler syndrome (MPS-IH). Bone Marrow Transplant 30:215-222

116. Ehtesham M, Kabos P, Gutierrez MA, Chung NH, Griffith TS, Black KL, Yu JS 2002 Induction of glioblastoma apoptosis using neural stem cell-mediated delivery of tumor necrosis factor-related apoptosis-inducing ligand. Cancer Res 62:7170-7174

117. Aboody KS, Brown A, Rainov NG, Bower KA, Liu S, Yang W, Small JE, Herrlinger U, Ourednik V, Black PM, Breakefield XO, Snyder EY 2000 Neural stem cells display extensive tropism for pathology in adult brain: evidence from intracranial gliomas. Proc Natl Acad Sci USA 97:12846-12851

118. Yip S, Aboody KS, Burns M, Imitola J, Boockvar JA, Allport J, Park KI, Teng YD, Lachyankar M, McIntosh T, O'Rourke DM, Khoury S, Weissleder R, Black PM, Weiss W, Snyder EY 2003 Neural stem cell biology may be well suited for improving brain tumor therapies. Cancer J 9:189-204

119. Ostenfeld T, Svendsen CN 2003 Recent advances in stem cell neurobiology. Adv Tech Stand Neurosurg 28:3-89

120. Magnitsky S, Watson DJ, Walton RM, Pickup S, Bulte JW, Wolfe JH, Poptani H
2005 In vivo and ex vivo MRI detection of localized and disseminated neural stem cell grafts in the mouse brain. Neuroimage 26:744-754

121. Li L, Baroja ML, Majumdar A, Chadwick K, Rouleau A, Gallacher L, Ferber I, Lebkowski J, Martin T, Madrenas J, Bhatia M 2004 Human embryonic stem cells possess immune-privileged properties. Stem Cells 22:448-456

122. Lanza R, Moore MA, Wakayama T, Perry AC, Shieh JH, Hendrikx J, Leri A, Chimenti S, Monsen A, Nurzynska D, West MD, Kajstura J, Anversa P 2004 Regeneration of the infarcted heart with stem cell derived by nuclear transplantation. Circ Res 94:820-827

123. Hwang WS, Ryu YJ, Park JH, Park ES, Lee EG, Koo JM, Jeon HY, Lee BC, Kang SK, Kim SJ, Ahn C, Hwang JH, Park KY, Cibelli JB, Moon SY 2004 Evidence of a pluripotent human embryonic stem cell line derived from a cloned blastocyst. Science 303:1669-1674

124. Klimanskaya I, Chung Y, Meisner L, Johnson J, West MD, Lanza R 2005 Human embryonic stem cells derived without feeder cells. Lancet 365:1636-1641

125. Martin MJ, Muotri A, Gage F, Varki A 2005 Human embryonic stem cells express an immunogenic nonhuman sialic acid. Nat Med 11:228-232

126. Arnhold S, Klein H, Semkova I, Addicks K, Schraermeyer U 2004 Neurally selected embryonic stem cells induce tumor formation after long-term survival following engraftment into the subretinal space. Invest Ophthalmol Vis Sci 45:4251-4255

127. Heng BC, Cao T, Haider HK, Wang DZ, Sim EK, Ng SC 2004 An overview and synopsis of techniques for directing stem cell differentiation in vitro. Cell Tissue Res 315:291-303 